UDC 004.942

Kucherenko Ye. I. ${ }^{1}$, Trokhimchuk S. N. ${ }^{2}$, Driuk O. D. ${ }^{3}$

${ }^{1}$ Dr. Sc., Professor, Professor of Department of Artificial Intelligence, Kharkiv National University of Radio Electronics, Ukraine ${ }^{2}$ Postgraduate student of Department of Artificial Intelligence, Kharkiv National University of Radio Electronics, Ukraine ${ }^{3}$ Postgraduate student of Department of Artificial Intelligence, Kharkiv National University of Radio Electronics, Ukraine

\title{
KNOWLEDGE-ORIENTED TECHNOLOGIES IN HIGHLY AUTOMATED PRODUCTION
}

The expansion of Zadeh-Mamdani method in problems of fuzzy inference on knowledge is considered. A modified method of fuzzy inference is proposed and justified. The proposed method is based on interpretation of components of fuzzy Petri nets as production rules and solving of logical equations in the state space of membership functions of the model, followed by their defuzzification.

The process of perceptron learning as procedure of adjusting the weights and shifts to decrease the difference between target and real signals on its output, using a definite tuning (learning) rule is defined. Modified methods of gradient procedures based on the method of back-propagation for multilayer neural networks are developed.

Application of the proposed approaches based on advanced hybrid models with solving the problems of fuzzy inference and operative informed decision making allowed to reduce the time to identify, locate and eliminate the causes of failure on the set of alternatives, which is confirmed by experiment.

The method appears to be universal in decision-making problems and allows to increase the adequacy of hybrid model and the accuracy of decisions.

Keywords: Zadeh-Mamdani, modification, knowledge, rules, inference, Petri net, dichotomy, defuzzification.

\section{NOMENCLATURE}

$\cup$ denotes the union of hybrid model components;

$\checkmark$ denotes the maximum of fuzzy parameters;

$\wedge$ denotes the minimum of fuzzy parameters;

* denotes the operation of element-wise vectors multiplication;

ANN stands for Artificial Neural Network;

FKB stands for Fuzzy Knowledge Base;

HM stands for Hybrid Model;

PN stands for Petri Net;

PR stands for Production Rule;

$a_{k}^{q M}$ is the $k$-th element of output vector in $M$-th layer for the element from the $q$-th sample;

$F$ is a fuzzy incidence function $F:(P \times T) \cup(T \times P)$;

$L_{k}$ are predicates corresponding to space decisions;

$L_{n}$ are predicates corresponding to logical decisions;

$L^{\prime}$ is a subset of production rules;

$M_{0}$ is a vector of fuzzy initial marking of fuzzy positions of a PN;

$\left\{M_{0}\right\}$ is a set of production rules;

$P$ is a finite set of positions in $\mathrm{PN}$;

$r$ is number of layer in ANN;

$S^{(A N N)}$ is an ANN-based model;

$S^{(k)}$ is a fuzzy state space;

$S^{M}$ is a number of neurons in the layer;

$T$ is a finite set of transitions in PN;

$\left\{a_{\gamma}\right\}$ is a set of perceptron outputs; $\left\{\tau_{i, j}\right\}$ is a set of discrete time characteristics referred to transitions, positions and components of incidence functions, where $i \in I, j \in J$.

\section{INTRODUCTION}

It is known that construction of $\mathrm{PN}$ and their representation by FKB rules is less time consuming process than usual approaches in computer-aided design. Note that Zadeh-Mamdani approaches are more functional compared to Takagi-Sugeno-Kang method, resolution method and others. This fact has determined the direction of research.

The aim of the research is to develop a HM based on integration of PN and PR on knowledge in problems of fuzzy inference. The work is actual and important for the purpose of making decisions about the state of technological object under uncertainty. This is especially important for automated approach to design the FKB, where an algorithm of object functioning causes problems in its knowledge-based interpretation.

\section{PROBLEM STATEMENT}

Suppose a hybrid model $S^{(k)}{ }_{H M}[1]$ which operates on the object under parametric and structural uncertainty.

Some part of the data is implemented in the form of fuzzy production rules $\{$ if / then $\alpha\}, \alpha \in \mathrm{A}$, which produce the FKB.

In problems where the linear approximation is not enough, linear models do not work well, so it is necessary to consider the application of ANN in problems of reproducing the complex dependencies, classification and identification of objects. 
For solving the applied problems in the work it is necessary:

- to propose and justify a new hybrid model based on the integration of PN, knowledge-based PR and ANN, as a means of selection of alternatives on the set of PN positions in problems of fuzzy inference;

- to solve the problem of ANN learning using methods based on gradient procedures;

- to propose and justify a modified method of fuzzy inference, based on interpretation of the components of fuzzy PN by production rules, solving the logical equations in a state space of membership functions and classifying the rules followed by defuzzification;

- to confirm the effectiveness of the approach by experiment;

- determine the prospects for further research.

\section{REVIEW OF THE LITERATURE}

Currently, there are many solutions for a wide class of problems, methods and models of intelligent control of production systems [2-4]. The main tools to implement the approaches are extensions of Petri nets [5] and knowledgeoriented methods and models based on fuzzy logic $[5,6]$, which help to decrease the degree of uncertainty of the solutions. ANN [7, 8] as an approach for modeling processes of different complexity is a universal tool of modeling, classification and pattern recognition.

The advantages of using the extended Petri nets for systems modeling are following:

- concurrency of processes representation;

- modeling of the dynamics of processes in the space of parameters state;

- convenient representation of determinism properties, probabilistic and fuzzy processes.

The main disadvantages of this approach are difficulty of continuous processes representation and existence of conflicts. This requires additional research.

Knowledge-oriented methods based on frame models, production rules, knowledge based on ontological spaces processing have an important advantage - that is, reducing uncertainty degree of processes and objects, as well as possibility of production rules reduction. This increases the performance in problems of inference. The disadvantage is the complexity of knowledge acquisition, tuning of membership functions of fuzzy processes and their interpretation.

The advantage of ANN is their focus on a wide class of problems of data mining in decision-making systems. The disadvantage is the complexity of training the ANN and interpretation of modeling results, determined by the nonlinear nature of the network structure.

In this paper, to implement the knowledge-oriented technologies, it is proposed to use new approaches for expansion and integration of hybrid models [1, 5], which have the advantages of partial models along with significant reduction of their disadvantages.

\section{MATERIALS AND METHODS}

Given PN in the form [1]:

$$
S^{(k)}=\left\langle P, T, F, M_{0}, L_{n}, L_{k},\left\{\tau_{i, j}\right\}\right\rangle \text {. }
$$

Components of model $S^{(k)}(1)$ are defined in a fuzzy state space $S^{(k)}: \mu(k) \rightarrow[0,1]$. Then HM can be represented as

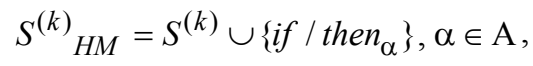

where $\{$ if / then $\alpha\}, \alpha \in \mathrm{A}$ is a set of fuzzy PR, $\alpha \in \mathrm{A}$ is a set of indexes of PR, $\cup$ is a character that defines the union of HM components, expanded functionally for procedures of Zadeh-Mamdani fuzzy inference [9]:

$$
y^{\prime}=\vee x^{\prime} \wedge \mu(x, y)_{H M} .
$$

Statement 1. If $\exists\left\{p_{j}\right\} \subset P, M \subset\left\{M_{0}\right\}, M_{p_{j}}>0 \mid\left\{p_{j}\right\} \neq \varnothing$ for any subset of rules $L^{\prime}$, then fuzzy inference can be implemented on $L^{\prime}$.

The correctness of the statement is obvious, given that the implementation of the rules on $L$ ' reduces the cardinality of the set of rules $\left|\left\{M_{0}\right\}\right|$, and this increases the speed of inference on rules.

Adequacy of fuzzy inference procedures (3) on model (2) is fully defined by interpretation (1). Indeed, let's consider a computational algorithm fragment

$$
A \stackrel{V}{\longrightarrow} M
$$

for which, using the interpretation rules (1), we obtain (fig. 1).

Then, using the reflection shown in fig. 1, we construct a rule from (2):

$$
\text { if } x \text { is } \mu(x) \rightarrow \text { «small» then } y \text { is } \mu(y) \rightarrow \text { «average» }
$$

with terms of the linguistic variables:

$$
\begin{gathered}
\mu(x)=\exp \left(-k_{1} x^{2}\right) \text { is «small», } \\
\mu(y)=\exp \left(-k_{2}(x-\beta)^{2}\right) \text { is «average». }
\end{gathered}
$$

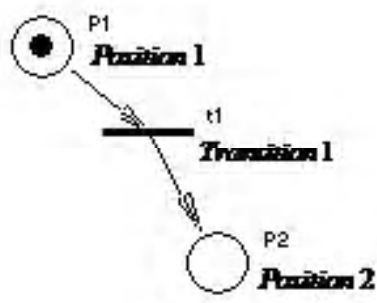

Figure 1 - Reflection of computational algorithm fragment

$$
A \stackrel{V}{\longrightarrow} M
$$


In the paper the problem of learning and tuning the parameters of membership functions $k_{1}, k_{2}, \beta(6),(7)$ is also solved. For this purpose, we used the method of dichotomy [10].

Using fuzzy Mamdani relation [9]:

$$
\mu(x, y)=\min (\mu(x), \mu(y)),
$$

we construct a matrix of relations, set the vector $x^{\prime}$ and find solution (5) based on (3) with further defuzzification based on mass center method. The adequacy of reflection of algorithm (4) is defined by setting in rule (5):

$$
x \rightarrow \text { position } p_{1}, y \rightarrow \text { position } p_{2},
$$

that is reflection of input $A$ and output $M$ respectively of the algorithm (4). Similarly we can show the adequacy of reflection for other algorithm fragments, confirmed by experiment.

Further development of modeling processes, including continuous ones, makes it necessary to use alternative procedures to extend the models (2).

Artificial neural networks (ANN) [11] are extremely powerful modeling tools, which allow to reproduce very complex dependencies. In particular, neural networks are nonlinear by their nature. For many years linear modeling was the main modeling method in most areas, as it had welldesigned optimization procedures. However, in problems where the linear approximation is not enough, linear models do not work well.

An important approach for further ANN models representation is perceptron [8], which is the most studied. Neuron used in the perceptron model has a step activation function hardlim with strict limitations (fig. 2).

Each element of the perceptron input vector is weighed with appropriate weight $w_{i j}$, and their sum is the input of the activation function. Perceptron neuron returns 1 , if activation function input $n>0$, or 0 , if $n>0$.

Activation function with strict limitations allows the perceptron to classify input vectors, dividing the space of the inputs into 2 areas, as it is shown in fig. 3 for the perceptron with two inputs and shift.

Input space is divided into two areas by separating line $L$, which in two-dimensional case is defined by the following equation:

$$
w^{T} p+b=0
$$

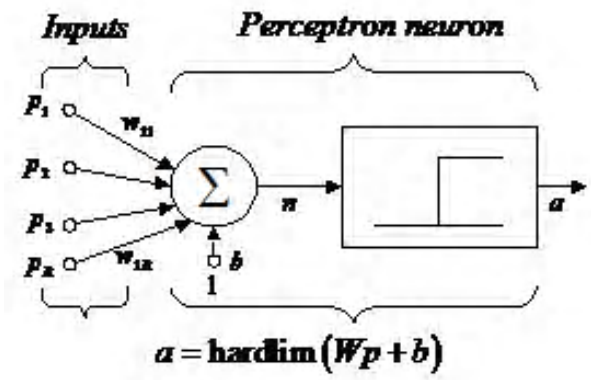

Figure 2 - Perceptron model

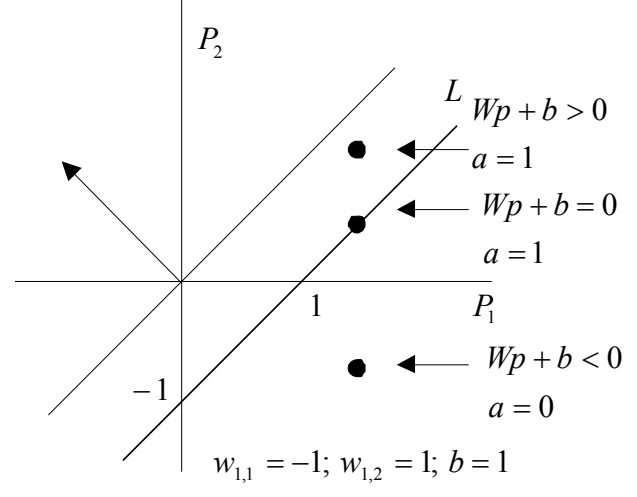

Figure 3 - Input vectors classification

This line is perpendicular to weight vector $w$ and is shifted by $b$. Input vectors above the line $L$ correspond to the positive potential of the neuron and, therefore, perceptron output for these vectors is equal to 1 ; vectors below the line correspond to perceptron output equal to 0 .

When changing the values of shift and weights, border of line changes its position. Perceptron without shift always forms the separating line passing through the coordinate origin; adding the shift forms the line which doesn't pass through the coordinate origin, as it is shown in fig. 3. If the dimension of the input vector is greater than 2, separating border appears to be a hyperplane.

Perceptron consists of a single layer including 5 neurons, as it is shown in fig. 4; weights $w_{i j}$ are transfer coefficients from $j^{\text {th }}$ output to $i^{\text {th }}$ neuron. Single-layer perceptron equation is as follows:

$$
a=f(W p+b) .
$$

Set of perceptron outputs (fig. 4) $\left\{a_{\gamma}\right\}, \gamma \in \mathrm{H}$ is the object of learning, and this appears to be a non-trivial task.

Suppose that model (2) is defined. It is focused on the discrete processes $P^{(D)}$. The requirement of the processing of strongly nonlinear continuous processes made it necessary to create a model $S_{\Sigma}^{(k)}$.

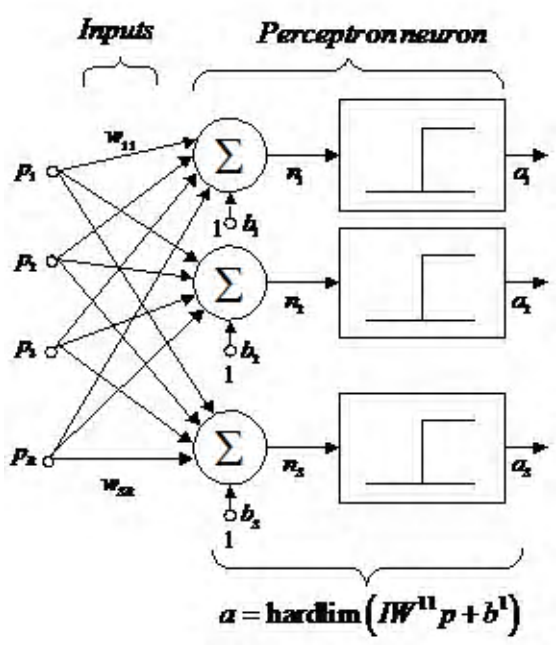

Figure 4 - Perceptron structure 
Statement 2. If we are given the model (2), its extension by assuming $\exists p_{j} \in P \mid p_{j}: M_{p_{j}}^{(A N N)} \neq \varnothing$ allows to expand the modeling and reliable decision-making area.

Correctness of statement 2 is obvious, if we consider the functional possibilities of ANN.

Then model $S_{\Sigma}^{(k)}$ can be represented in the following form:

$$
S_{\Sigma}^{(k)}=S^{(k)} \cup S^{(A N N)} .
$$

Statement 3. Given a model (10), the set of alternatives for any position

$$
p_{j} \in P \mid M_{p_{j}}^{(A N N)} \neq \varnothing
$$

determines the development of processes $(D)$ in the set of output transitions

$$
p_{j} \in\left\{p_{i}\right\} \mid \exists t_{i} \in\left\{t_{j}(\text { out })\right\}, t_{i} \rightarrow D
$$

of the PN (1).

If the network (10) holds (11) and (12), then the problem of learning the network $S^{(A N N)}$ occurs.

\section{EXPERIMENTS}

Define the process of perceptron learning as procedure of adjusting the weights and shifts to decrease the difference between target and real signals on its output, using a definite tuning (learning) rule. Training procedures are divided into two classes: supervised learning and unsupervised learning.

Once the initial weights and shifts of the neurons are set by user or using random number generator, the network is ready to start its training procedure [5]. The most important learning methods can be considered the methods based on gradient learning procedures. Neural networks designed to solve practical problems can contain up to several thousands of adjustable parameters, so calculation of the gradient may require a rather high cost of computing resources. Given the specificity of multilayer neural networks, there are developed special methods of calculating the gradient, among which we should highlight the back-propagation method.

The term «back-propagation» refers to the process with which derivatives of the error functional by network parameters can be calculated. This process can be used in combination with different optimization strategies. There are also a lot of variations of back-propagation algorithm.

Consider the expression for the gradient of quality criterion by weighting coefficients for the output layer $M$ of the network:

$$
\begin{gathered}
\frac{\partial J}{\partial w_{i j}^{M}}=\frac{\partial}{\partial w_{i j}^{M}}\left(\frac{1}{2} \sum_{q=1}^{Q} \sum_{k=1}^{S^{M}}\left(t_{k}^{q}-a_{k}^{q S^{M}}\right)^{2}\right)=-\sum_{q=1}^{Q} \sum_{k=1}^{S^{M}}\left(t_{k}^{q}-a_{k}^{q M}\right) \frac{\partial a_{k}^{q M}}{\partial w_{i j}^{M}} \\
i=1, \ldots, S^{M}, j=0, \ldots, S^{M-1}
\end{gathered}
$$

Functioning rule of layer $M$ is as follows:

$$
a_{k}^{q M}=f_{M}\left(\sum_{l=0}^{S^{M-1}} w_{k l}^{M} a_{l}^{q(M-1)}\right), m=1, \ldots, S^{M} .
$$

From the equation (13) we receive:

$$
\frac{\partial a_{k}^{q M}}{\partial w_{i j}^{M}}=\left\{\begin{array}{l}
0, \quad k \neq i \\
f^{\prime}\left(n_{i}^{q M}\right) a_{j}^{q(M-1)}, k=i \\
i=1, \ldots, S^{M-1}, \\
j=0, \ldots, S^{M-1} .
\end{array}\right.
$$

Substituting (15) into (13) we obtain:

$$
\frac{\partial J}{\partial w_{i j}^{M}}=-\sum_{q=1}^{Q}\left(t_{i}^{q}-a_{i}^{q M}\right) f_{k}^{\prime}\left(n_{i}^{q M}\right) a_{i}^{q(M-1)} .
$$

If we denote

$$
\Delta_{i}^{q M}=\left(t_{i}^{q M}-a_{i}^{q M}\right) f_{M}^{\prime}\left(n_{i}^{q M}\right), i=1, \ldots, S^{M},
$$

we receive:

$$
\frac{\partial J}{\partial w_{i j}^{M}}=-\sum \Delta_{i}^{q M} a_{i}^{q(M-1)} ; i=1, \ldots, S^{M}, j=1, \ldots, S^{M-1}
$$

After calculating the weights $w_{i j}^{M-1}$ of layer $M-1$, we receive the following general formula:

$$
\begin{gathered}
\frac{\partial J}{\partial w_{i j}^{r}}=-\sum_{q=1}^{Q} \Delta_{i}^{q(r-1)} a_{j}^{q(r-1)}, r=1, \ldots, M, \\
i=1, \ldots, S^{r}, j=0, \ldots, S^{r-1},
\end{gathered}
$$

where

$$
\begin{gathered}
\Delta_{i}^{q r}=\left(\sum_{k=1}^{S^{r+1}} \Delta_{k}^{q(r+1)} w_{k i}^{r+1}\right) f_{r}^{\prime}\left(n_{i}^{q r}\right), r=1, \ldots, M-1, \\
\Delta_{i}^{q M}=\left(t_{i}^{q}-a_{i}^{q M}\right) f_{M}^{\prime}\left(n_{i}^{q M}\right), i=1, \ldots, S^{M} .
\end{gathered}
$$

Fig. 5 shows a diagram of calculations [12] corresponding to the expression (19).

In this diagram symbol ** denotes multiplication of vectors $\Delta$ and $a^{T}$.

\section{RESULTS}

In our research the system of statements justifying the extension of hybrid models in the form of integration of PN, fuzzy PR and ANN is formulated. The development of such models has allowed to implement the effective management of intellectual processes.

For ANN training gradient procedures on the basis of back-propagation of errors are proposed. In fig. 6 we can see the dependency between the number of performed training iterations and resulting error. This graph is built using function train in Matlab. 


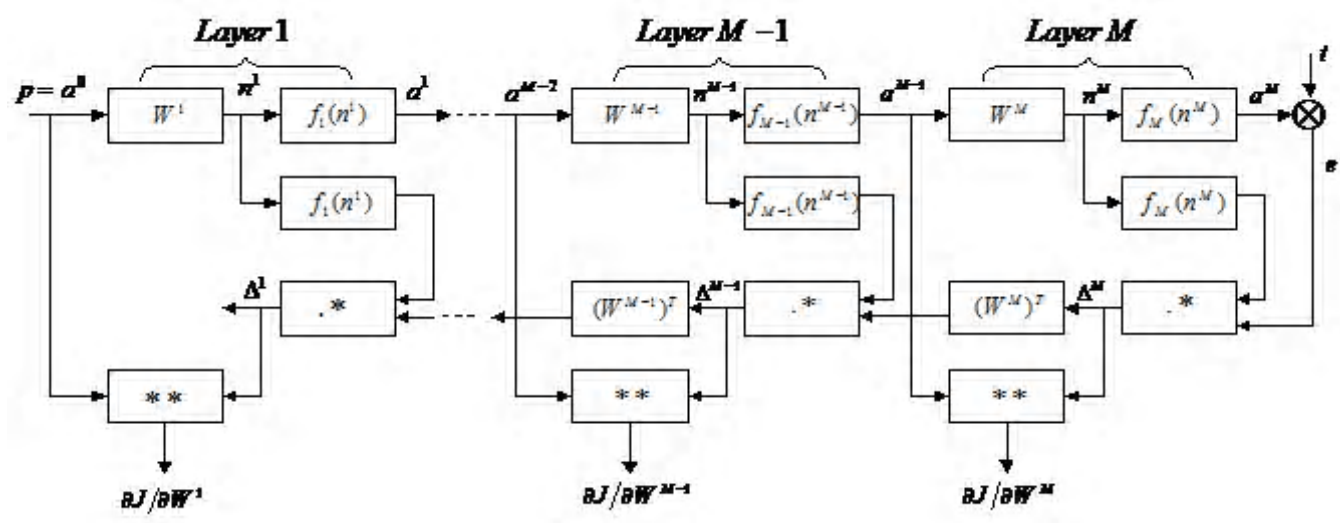

Figure 5 - Diagram of calculations

\section{DISCUSSION}

As noted in earlier publications [13], currently unique high-production machine-assembly areas of machinery enterprises have a modern production base including robot manipulators and cylindrical grinding machines with numerical control of foreign and domestic production equipped with active control systems, which allow realizing the management and control of the technological process. The scheme of the production unit is usually equipped with highly automated equipment with inductive transducer and the electronic measuring system with discrete 0,$01 ; 0,1$ microns and error $<0,5 \%$.

In case of failure of the system, serious financial losses can occur, and it will affect the cost $C$ of final product.

Application of the proposed approaches based on hybrid models (2), (9) with solving the problems of fuzzy inference and operative informed decision making allowed to reduce on the set of alternatives (11), (12) the time $\tau$ to identify, locate and eliminate the causes of failure to 20 minutes, having the linguistic terms of maintenance stuff professional fitness «average» and higher, which is confirmed by experiment.

\section{CONCLUSION}

Thus, we propose a new hybrid model based on the integration of PN, knowledge-based production rules and ANN as a tool of selection of alternatives on the set of PN

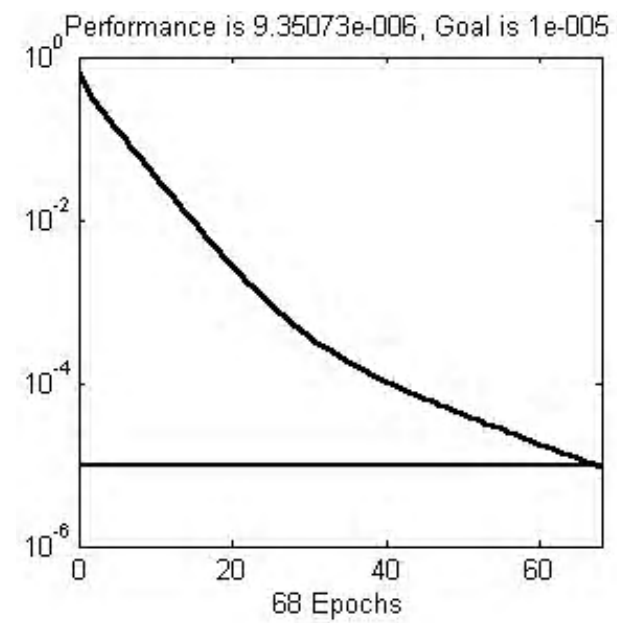

Figure 6 - Dependency between number of iterations and resulting error positions in fuzzy inference problems. The problem of ANN training by methods based on the gradient procedures is formulated and solved. Modified method of fuzzy inference is proposed and justified. This method is based on the interpretation of the components of fuzzy $\mathrm{PN}$ by production rules and logical equations solving in the state space of membership functions of the model, and also rules classification with further defuzzification. Experiment confirmed the effectiveness of the approach. The prospects of further studies are identified.

\section{REFERENCES}

1. Кучеренко Е. И. Гибридные модели и информационные технологии в управлении сложными объектами / Е. И. Кучеренко., С. Н. Трохимчук // Комп'ютерно-інтегровані технології: освіта, наука, виробництво. - Луцьк : ЛНТУ, 2013. - C. 46-51.

2. Конкин Р. В. Методы ранжирования данных с учетом свойств нечетких систем / Р.В. Конкин // Вісник НТУ «ХПІ». Серія Нові рішення в сучасних технологіях. - Х. : НТУ «ХПІ».2013. - № 1 (977). - C. 26-30.

3. Jensen R. Computational intelligence and feature selection: rough and fuzzy approaches / R. Jensen, Q. Shen. - Hoboken : John Wiley \& Sons, 2008. - 339 p.

4. Jang J. R. ANFIS: Adaptive-network-based fuzzy inference system / J. R. Jang // IEEE transactions on systems and cybernetics. 1993. - Vol. 23. - P. 665-685. DOI: 10.1109/21.256541.

5. Бодянский Е. В. Нейро-фаззи сети Петри в задачах моделирования сложных систем : монография / Е. В. Бодянский, Е. И. Кучеренко, А. И. Михалев. - Дніпропетровськ : Системні технології, 2005. - $311 \mathrm{c.}$

6. Subbotin S. The neuro-fuzzy network synthesis and simplification on precedents in problems of diagnosis and pattern recognition / S. Subbotin // Optical Memory and Neural Networks (Information Optics). - 2013. - Vol. 22, № 2. - P. 97-103. DOI: $10.3103 / \mathrm{s} 1060992 \times 13020082$

7. Руденко О. Г. Основы теории искусственных нейронных сетей / О. Г. Руденко, Е. В. Бодянский. - Харьков : ТЕЛЕТЕХ, 2002. - 317 c.

8. Тарасенко О. П. Нейронно-мережні моделі якості : монографія / О. П. Тарасенко, С. М. Трохимчук. - Харків : УІПА, 2013. - 115 c.

9. Tsoukalas L. H. Fuzzy and Neural Approaches in Engineering / L. H. Tsoukalas, R. E. Uhrig. - New York : John Wiley\&Sons.Inc, 1997. - 587 p.

10. Методи, моделі та інформаційні технології оцінювання станів складних об'єктів / Кучеренко Є. І., Кучеренко В. Є., Глушенкова I. С., Творошенко I. С. - Харків : ХНАМГ, ХНУРЕ, 2012. -276 c. 
11. Бодянский Е. В. Интеллектуальное управление технологическими процессами : монография / Е. В. Бодянський, Е. И. Кучеренко, А. И. Михалев и др.]. - Днепропетровск : Национальная металлургическая академия Украины, 2013. $213 \mathrm{c}$.

12. Бодянский Е. В. Основы теории искусственных нейронных сетей : монография / Е. В. Бодянский. О. Г. Руденко. - Харьков : ТЕЛЕТЕХ, 2002. - 317 c.
13. Кучеренко Е. И. Метод оценивания качества изделий механосборочного производства/ Е. И. Кучеренко, С. Н. Трохимчук // Збірник наукових праць Харківського університету Повітряних Сил. - 2014. - Вип. 2 (39). C. $183-189$.

Article was submitted 13.10.2014 After revision 19.10.2014.

Кучеренко Е. И. ${ }^{1}$, Трохимчук С. Н. ${ }^{2}$, Дрюк А. Д. ${ }^{3}$

${ }^{1}$ Д-р техн. наук, профессор Харьковского национального университета радиоэлектроники, Украина

${ }^{2}$ Аспирант Харьковского национального университета радиоэлектроники, Украина

${ }^{3}$ Аспирант Харьковского национального университета радиоэлектроники, Украина

ЗНАНИЕ-ОРИЕНТИРОВАННЫЕ ТЕХНОЛОГИИ В ВЫСОКОАВТОМАТИЗИРОВАННЫХ ПРОИЗВОДСТВАХ

Рассматривается расширение метода Заде-Мамдани в задачах нечеткого логического вывода, основанного на знаниях. Предложен и обоснован модифицированный метод нечеткого логического вывода, основанный на интерпретации компонент нечетких сетей Петри как правил продукции и решении логических уравнений в пространстве состояний функций принадлежности модели с последующей дефаззификацией.

Определен процесс обучения персептрона как процедуры настройки весов и смещений с целью уменьшить разность между желаемым (целевым) и истинным сигналами на его выходе, используя некоторое правило настройки (обучения). Для многослойных нейронных сетей разработаны модифицированные методы градиентных процедур, основанных на методе обратного распространения ошибки.

Применение предлагаемых подходов на основе расширенных гибридных моделей с решением задач нечеткого логического вывода и оперативного принятия обоснованных решений позволило на множестве альтернатив сократить время выявления, локализации и ликвидации причин отказа, что подтверждено экспериментом.

Метод является универсальным в задачах принятия решений и позволяет повысить адекватность гибридных моделей и точность принятия решений.

Ключевые слова: Заде-Мамдани, модификация, знания, правила, логический вывод, сети Петри, дихотомия, дефаззификация.

Кучеренко Є. І. ${ }^{1}$, Трохимчук С. Н. ${ }^{2}$, Дрюк О. Д. ${ }^{3}$

${ }^{1}$ Д-р техн. наук, професор Харківського національного університету радіоелектроніки, Україна

${ }^{2}$ Аспірант Харківського національного університету радіоелектроніки, Україна

${ }^{3}$ Аспірант Харківського національного університету радіоелектроніки, Україна

\section{ЗНАННЯ-ОРІЕНТОВАНІ ТЕХНОЛОГІЇ У ВИСОКОАВТОМАТИЗОВАНИХ ВИРОБНИЦТВАХ}

Розглядається розширення методу Заде-Мамдані у задачах нечіткого логічного виведення, що засноване на знаннях. Запропонований та обгрунтований модифікований метод нечіткого логічного виведення, заснований на інтерпретації компонент нечітких сіток Петрі як правил продукції та розв'язанні логічних рівнянь у просторі станів функцій належності моделі з подальшою дефаззіфікацією.

Визначено процес навчання персептрона як процедури налаштування ваг та зміщень 3 метою зменшити різницю між бажаним (цільовим) та справжнім сигналами на його виході, використовуючи деяке правило налаштування (навчання). Для багатошарових нейронних мереж розроблені модифіковані методи градієнтних процедур, заснованих на методі зворотного поширення помилки.

Застосування запропонованих підходів на основі розширених гібридних моделей з розв'язанням задач нечіткого логічного виведення та оперативного прийняття обгрунтованих рішень дозволило на множині альтернатив скоротити час виявлення, локалізації та ліквідації причин відмови, що підтверджено експериментом.

Метод $є$ універсальним у задачах прийняття рішень та дозволяє підвищити адекватність гібридних моделей та точність прийняття рішень.

Ключові слова: Заде-Мамдані, модифікація, знання, правила, логічне виведення, сітки Петрі, дихотомія, дефаззіфікація.

\section{REFERENCES}

1. Kucherenko Ye. I., Trokhimchuk S. N. Gibridnyye modeli i informatsionnyye tekhnologii $\mathrm{v}$ upravlenii slozhnymi ob'yektami, Komp'yuterno-intehrovani tekhnolohiyi: osvita, nauka, vyrobnytstvo. Lutsk, LNTU, 2013, pp. 46-51.

2. Konkin R.V. Metody ranzhirovaniya dannykh s uchetom svoystv nechetkikh sistem, Visnyk NTU «KhPI». Seriya Novi rishennya $v$ suchasnykh tekhnolohiyakh. Kharkiv, NTU «KhPI», 2013, No. 1 (977), pp. 26-30.

3. Jensen R., Shen Q. Computational intelligence and feature selection: rough and fuzzy approaches. Hoboken, John Wiley \& Sons, 2008, $339 \mathrm{p}$.

4. Jang J. R. ANFIS: Adaptive-network-based fuzzy inference system, IEEE transactions on systems and cybernetics, 1993, Vol. 23, pp. 665-685. DOI: 10.1109/21.256541.

5. Bodyanskiy Ye. V., Kucherenko Ye. I., Mikhalev A. I. Neyrofazzi seti Petri v zadachakh modelirovaniya slozhnykh sistem : monohrafiya. Dnipropetrovs'k, Systemni tekhnolohiyi, 2005, $311 \mathrm{p}$.

6. Subbotin S. The neuro-fuzzy network synthesis and simplification on precedents in problems of diagnosis and pattern recognition, Optical Memory and Neural Networks (Information
Optics), 2013, Vol. 22, No. 2, pp. 97-103. DOI: 10.3103/ s1060992x13020082

7. Rudenko O. G., Bodyanskiy Ye. V. Osnovy teorii iskusstvennykh neyronnykh setey. Kharkov, TELETEKH, 2002, 317 p.

8. Tarasenko O. P., Trokhymchuk S. M. Neyronno-merezhni modeli yakosti :monohrafiya. Kharkiv, UIPA, 2013, 115 p.

9. Tsoukalas L. H., Uhrig R. E. Fuzzy and Neural Approaches in Engineering. New York, John Wiley\&Sons.Inc, 1997, 587 p.

10. Kucherenko Ye. I., Kucherenko V. Ye., Hlushenkova I. S., Tvoroshenko I. S. Metody, modeli ta informatsiyni tekhnolohiyi otsinyuvannya staniv skladnykh ob'yektiv : monografiya. Kharkiv, KhNAME, KhNURE, 2012, 276 p.

11. Bodyanskiy Ye. V., Kucherenko Ye. I., Mikhalev A. I., Filatov V. A., Gasik M. M., Kutsin V. S. Intellektual'noye upravleniye tekhnologicheskimi protsessami : monografiya. Dnepropetrovsk, Natsional'naya metallurgicheskaya akademiya Ukrainy, 2013, 213 p.

12. Bodyanskiy Ye. V., Rudenko O. G. Osnovy teorii iskusstvennykh neyronnykh setey : monografiya. Kharkov, TELETEKH, 2002, $317 \mathrm{p}$.

13. Kucherenko Ye. I., Trokhimchuk S. N. Metod otsenivaniya kachestva izdeliy mekhanosborochnogo proizvodstva, Zbirnyk naukovykh prats' Kharkivs'koho universytetu Povitryanykh Syl, 2014, Iss. 2(39), pp. 183-189. 